\title{
JOURNAL.RU
}

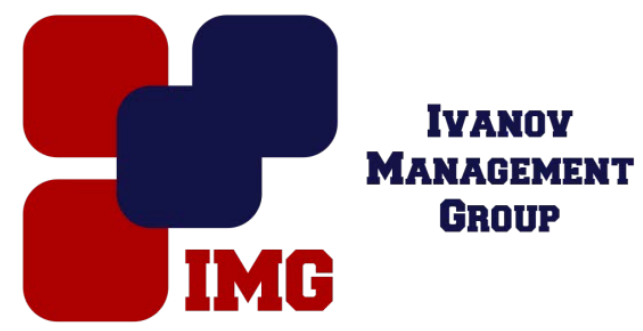

\author{
Подлепаева А.В., Солозобова Н.С., Горшков Н.В., Маркелова О.А., \\ Дударева О.А., Лясникова А.В., Пичхидзе С.Я. \\ СГТУ им. Ю.А. Гагарина \\ Саратов, Россия
}

doi: 10.18411/lj-25-12-2016-1-10

idsp 000001:lj-25-12-2016-1-10

\section{РФА металлсодержащих ТКФ}

Известно, что для металлсодержащей кальцийфосфатной биокерамики рентгенофазовый анализ (РФА) является требуемой частью исследования [1,2].

Цель работы заключалась в получении рентгенофазовых спектров синтезированных металлсодержащих трикальцийфосфатов (Met-ТКФ).

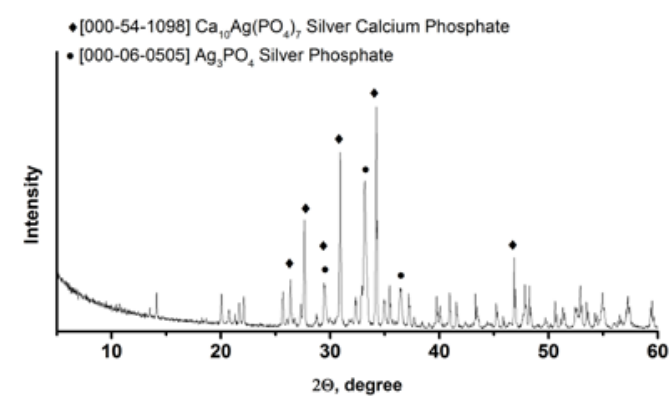

$A g-T K \Phi$

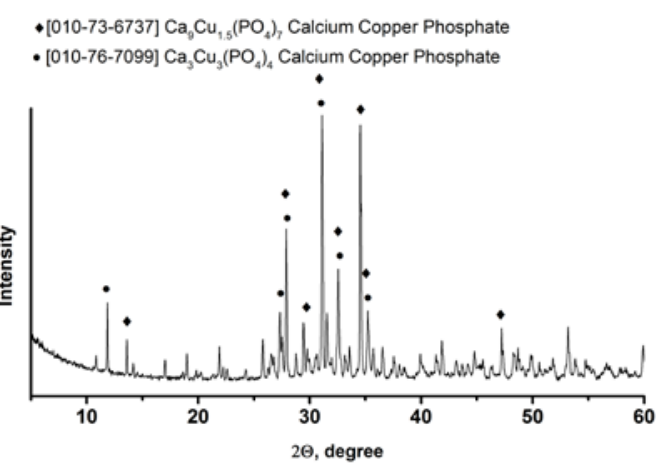

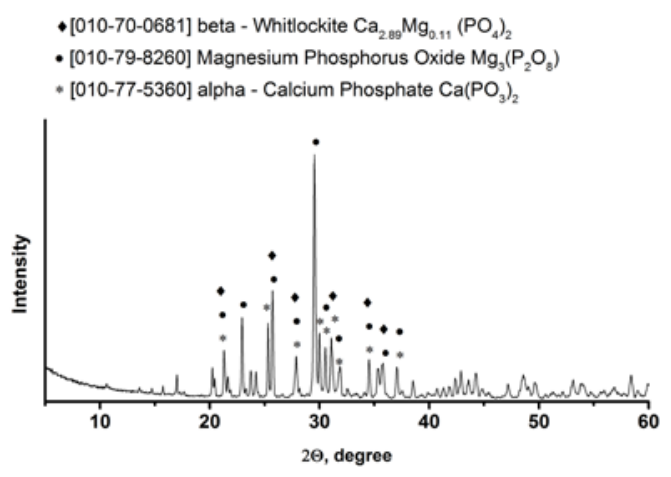

$M g-T K \Phi$

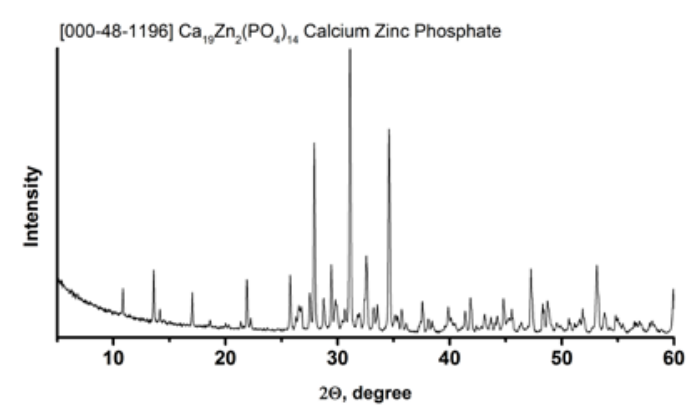

Сu-TKФ 
Выводы: проведен РФА синтезированных металлсодержащих трикальцийфосфатов и доказана их структура.

\section{Литература}

1. Смоленко Д.М., Горбачев И.А., Костин К.Б., Маркелова О.А., Дударева О.А., Лясникова А.В., Пичхидзе С.Я. Идентификация цинк-содержащего ТКФ. Тенденции науки и образования в современном мире. Самара: ЛЖурнал, 2016. № 12-2. С. 22-23.

2. Подлепаева А.В., Костин К.Б., Горшков Н.В., Маркелова О.А., Дударева О.А., Лясникова А.В., Пичхидзе С.Я. Идентификация металлсодержащих ТКФ. 17 МНК, Самара: Л-Журнал, 31.08.2016.-С.37. 